IBAD Sosyal Bilimler Dergisi

IBAD Journal of Social Sciences

dergipark.org.tr/ibad

IBAD, 2021; (10): 248-263

DOI: $10.21733 /$ ibad.850705

Derleme / Review Article

\title{
Bağlanma Kuramı Çerçevesinde Aldatma ve Boşanma
}

Deception and Divorce Within the Framework of Attachment Theory

\section{Eda Kaya Örk}

\author{
* Sorumlu yazar \\ Corresponding author
}

${ }^{1}$ Uzman Sosyal Çalışmacı, Selçuk Üniversitesi, Türkiye

Expert Social Worker, Selçuk University, Turkey

eda.kaya327@hotmail.com

ORCID ID 0000-0002-3789-9166

Makale geliş tarihi / First received : 30.12 .2020

Makale kabul tarihi / Accepted : : 15.03.2021

\section{Bilgilendirme / Acknowledgement:}

Yazar aşağıdaki bilgillen dirmeleri yapmaktadır:

1- Eşim Ali ÖRK ve Doktor Öğretim Üyesi Sinan AKÇAY'a desteklerinden dolayı TEŞEKKÜR ederim.

2- Makalemizde etik kurulu izni ve/veya yasal/özel izin alınmasını gerektiren bir durum yoktur. Derleme bir çalışmadır.

3- Bu makalede araştırma ve yayın etiğine uyulmuştur.

This article was checked by Turnitin. Similarity Index \%3

\section{Atıf bilgisi / Citation:}

Kaya Örk, E. (2021). Bağlanma kuramı çerçevesinde aldatma ve boşanma. IBAD Sosyal Bilimler Dergisi, (10), 248263. 
ÖZ

Geçmişten günümüze evlilik ilişkilerinin en yaygın çatışma sebeplerinden olan aldatma olgusu, kimi zaman ilişkinin sonlanmasına kadar gidebilen yıkıcı etkilere sahiptir. Aldatma; toplumsal, kültürel ve dinsel öğretiler ile yanlış olarak etiketlense de görülme sıklığ1 oldukça yüksektir. Bu derleme çalışmasının amacı aldatma ve boşanma ilişkisini Bağlanma Kuramı perspektifinden değerlendirmektir. Çalışmada önce yetişkin bağlanma stilleri ve evlilik uyumu ilişkisi ele alınmış, daha sonra bağlanma stilleri ile aldatma eğilimi ve boşanma ilişkisi değerlendirilmiştir. Kuramsal açıdan bağlanma ilişkisi, bebeğin bakımverenle ilişkisine bağlı olarak gelişmektedir. Bu bağlanma stilleri yetişkinlikte de etkisini korumakta ve yetişkin bağlanma stilleri romantik ilişkilerde dinamikleri, iletişim becerilerini ve çatışma çözüm stratejilerini belirlemede oldukça etkili konuma gelmektedir. Yetişkin bağlanma stilleri evlilikte aldatma eğilimini anlamlandırmada kilit noktalardan biridir. Ülkemizde aldatma konusuyla ilgili yapılan çalışmalar sınırlıdır ve bağlanma stilleri ile aldatma ve boşanma ilişkisini ele alan çalışma bulunmamaktadır. Çalışma, oldukça güncel bir konu olan aldatmayı bağlanma kuramı perspektifinden ele alması bakımından önemlidir. Çalışmada derlenen bulgular, evlilikte dinamikleri anlamlandırma ve çatışmalara çözüm bulma noktasında alanyazına ve uygulayıcılara izlenecek yollara ilişkin önemli bir perspektif kazandıracaktır.

\section{Anahtar kelimeler}

Bağlanma stilleri, yetişkin bağlanma stilleri, evlilik, aldatma, boşanma

\section{ABSTRACT}

The phenomenon of infidelity, which is one of the most common causes of conflict in marital relations from the past to the present, sometimes has devastating effects that can lead to the end of the relationship. Deception; it is labeled as wrong with social, cultural and religious teachings, but its incidence is quite high. The purpose of this review study is to evaluate the relationship between infidelity and divorce from the perspective of The Theory of Attachment. In the study, firstly, the relationship between adult attachment styles and marital adjustment was examined, then the relationship between attachment styles and cheating tendency and divorce was evaluated. The theoretical attachment relationship is developed depending on the baby's relationship with the care giver. For this reason, attachment styles maintain their importance in adulthood, and adult attachment styles are quite common in determining the dynamics, communication skills and conflict resolution strategies in romantic relationships. Adult attachment styles are one of the key points in ing meaning the tendency to cheat in marriage. Studies on infidelity in our country are limited, and there are no studies dealing with attachment styles and the relationship between infidelity and divorce. The study is important in that it deals with deceit, which is a very current topic, from the perspective of attachment theory. This study will provide an important perspective for the literature and practitioners to understand the dynamics of marriage and resolve conflicts.

\section{Keywords}

Attachment styles, adult attachment styles, marriage, infidelity, divorce 


\section{GİRIŞ}

Bebeklik bağlanma stilleri, bebeğin bakımveren ile kurduğu ilişkiyi ele almakta ve bu bağlanmanın kişilik gelişimine olan etkisine dikkat çekmektedir. Bu noktada bebeğin duygusal ihtiyaçlarının en az fizyolojik ihtiyaçları kadar önemli olduğu görülmektedir. Bağlanmanın klinik açıdan bir diğer önemi ise bebeğin şu anki yaşına bakılmaksızın kişiliği üzerindeki etkisidir (Bowbly, 2012). Bu durum bebeklik bağlanma stillerinin kişinin çocukluktan yetişkinliğe uzanan süreçte; gelişiminde ve kurduğu ilişkilerde etkili olduğunu göstermektedir. Nitekim Hazan ve Shaver (1987) bebeklik bağlanma stillerinin bireylerin gelecek yaşamlarındaki arkadaş ilişkileri ile romantik ilişkilerini doğrudan etkilediğini ifade etmektedir.

Yetişkin bağlanma stilleri, çocukluk döneminde bebeğin bakımveren ile kurduğu bağlanma ilişkisinin, ileriki yaşlarda duygusal ve sosyal yaşamını etkilemesi bakımından önemlidir. Bartholomew ve Horowitz (1991) güvenli, kayıtsız, korkulu ve saplantılı olmak üzere “Dörtlü Bağlanma Modeli" geliştirilmişlerdir. Buna göre güvenli bağlanan kişiler; kendilerini ve başkalarını sevilmeye değer olarak görürler. Saplantılı bağlanan kişiler ise kendilerini sevilmeye layık olarak görmezken başkalarına ilişkin düşünceleri olumludur. Korkulu bağlanma stiline sahip kişilerin kendilerine ve başlarına ilişkili düşünceleri olumsuzdur. Kaçınan bağlanma stilindeki kişiler ise kendilerini sevilmeye değer görmelerine karşın başkalarına yönelik düşünceleri olumsuzdur.

Yetişkin bağlanma stilleri bireylerin romantik ilişkilerini büyük oranda etkilemektedir. Bu noktada kişinin partneriyle kurduğu bağlanma ilişkiye; iletişim, ilişki doyumu ve aldatma eğilimi gibi farklı boyutlarda etki etmektedir. Bu sebeple bağlanma stillerinin romantik ilişkilere ve evlilik uyumuna etkisi üzerine alanyazında pek çok çalışma bulunmaktadır (Banse, 2004; Kobak ve Hazan, 1991).

Bağlanma bireyin yaşına bakılmaksızın hissettiği duyguların yoğunluğudur. Bu nedenle bireyin romantik ilişkilerindeki duygusal yoğunluğu, ilişkinin temellerini anlamlandırabilmek açısından büyük önem taşımaktadır. Bu temeller evlilik ilişkisinin; ilişki doyumu, aldatma ve boşanma gibi farklı açılardan ele alınmasını kolaylaştırmaktadır. Yetişkin bağlanma stilleri öznesinde; aldatma ve boşanma ilişkisinin incelenmesi, evlilikte dinamikleri anlamlandırma ve çatışmalara çözüm bulma noktasında bireylere, araştırmacılara ve uygulayıcılara yeni bir perspektif sunabilir. Yetişkin bağlanma stilleri ile aldatma ve boşanma ilişkisi incelenirken; erkek ve kadının ilişkiye yüklediği anlamlar, duygusal ve cinsel tatminleri, beklentilerinin ne kadar karşılandığ (Demir, 2016) gibi farklı dinamikler de göz önüne alınmalıdır. Bu dinamikler, her ilişkinin kendi içinde biricik ve özel olması ile ilişkilidir.

Alanyazın incelendiğinde ülkemizde bağlanma stilleri ile aldatma eğilimi ilişkisini ele alan çalışmalar sınırlıdır ve bağlanma stilleri ile aldatma ve boşanma ilişkisini ele alan herhangi bir çalışma bulunmamaktadır. Aile dinamiklerini etkileyen bağlanma stillerinin, aldatmaya ve evliliklerin sonlanmasına etkisi göz önüne alındığında, çalışmanın literatüre ve uygulayıcılara katkı sağlayacağı düşünülmektedir. Araştırma bilimsel yöntemlere uygun olarak, gerekli kavramlar ve konular üzerinde literatür taraması yapılarak (belgesel gözlem tekniği ile) açıklanmaya çalışılmıştır. 


\section{Bağlanma Kuramı ve Yetişkin Bağlanma Stilleri}

Bowlby (1973) bağlanmayı kişilerin stresli olduğu ya da korktuğu zamanlarda bir nesne ile yakınlık kurmak veya ilişki geliştirmek için hissettiği istek/arzu olarak tanımlamıştır. Buna göre bağlanma stilleri ile paralellik gösteren ebeveynlik stilleri psikolojik ve fiziksel olarak sağlıklı, aynı zamanda kendine güveni yüksek bireylerin yetişmesinde oldukça önemlidir. Bowly'e göre erken dönemde sevgi ve güvenle yetişen çocuk, ilerleyen dönemlerde güvenilmeye ve sevilmeye değer bir insan olduğunu düşünecektir (Bowbly, 1973).

Ainsworth'e göre çocuklukta geliştirilen üç tür bağlanma bulunmaktadır. Ainsworth bu bağlanma stillerini güvenli, güvensiz ve kayıtsız olarak sinıflandırmaktadır. Güvenli bağlanma bebeklikteki tutarlı ve duyarlı bakımın sonucunda gelişir. Bu bebekler çevreyi keşfetmeye eğilimlidirler çünkü bakıcılarının erişilebilir olduğuna güven duymaktadırlar. Bakımveren kişi bebekten uzaklaştığında oluşan sıkıntı yeniden bir araya geldikten sonra azalır ve keşfe geri dönülür. Güvensiz bağlanma gerçekleştiren bebekler ise bakımveren kişinin varlığında dahi keşfe çıkmakta isteksizdirler. Bakımverenden uzaklaşmak onları son derece rahatsız eder. Bakımverenle tekrar bir araya geldiklerinde ise öfkeli bir ruh hali sergilemektedirler. Kayıtsız bağlanma stili; bakımveren kişinin teması reddetmesi ve kayıtsızlığı sonucu ortaya çıkmaktadır. Bu bağlanmayı gerçekleştiren bebekler, güvensiz bağlanan bebeklerin aksine bakımverenin varlığı ile meşgul olmazlar. Bakımverenden ayrıldıklarında sıkıntı belirtisi göstermez ve hatta aktif olarak temastan kaçınırlar (Selçuk, Zayas ve Hazan, 2010).

Ainsworth (1989) bağlanmanın altında yatan davranışın nörofizyolojik süreçlerden kaynaklandığı düşünülen içsel süreçleri içerdiğini belirtmektedir. Buna göre içsel süreçler; genetik ve çevresel faktörlerin etkisiyle gelişimlere ve değişimlere maruz kalır. Bowlby ve Ainsworth, bağlanma stillerinin, erken dönemdeki ebeveyn etkileşimini, ilerleyen dönemde ise inançları, beklentileri, ihtiyaçları ve diğer sosyal davranışları etkilediğini belirtmişlerdir. Buna göre bağlanma sadece çocukluk dönemini değil tüm yaşamı kapsamaktadır. Erken dönemde bakımveren ile bebek ilişkisi, ileri dönemlerdeki bağlanmaların temelini oluşturmaktadır (Varlık Özsoy, 2015).

Hazan ve Shaver (1987) bebeklik bağlanma stillerinin, bireylerin gelecek yaşamlarındaki arkadaş ilişkileri ile romantik ilişkilerini doğrudan etkilediğini ifade etmektedir. Buna göre güvenli, kaygılı ve kaçınan bağlanma stilleri yetişkinlikte de görülebilmektedir. Sonraki yıllarda Bartholomew ve Horowitz (1991) yetişkin bağlanma stillerini Bowlby'nin "başkalarına" ve "benliğe" yönelik temsilleri bağlamında farklı biçimde ele almıştır. Buna göre benlik ile başkaları temsillerinin olumlu ya da olumsuz olmasına göre "Dörtlü Bağlanma Modeli" geliştirmişlerdir. Bu model güvenli, kayıtsız, korkulu ve saplantılı bağlanma stillerini kapsamaktadır. 
Tablo 1. Yetişkin Bă̆lanma Stilleri (Bartholomew ve Horowitz, 1991, s. 227).

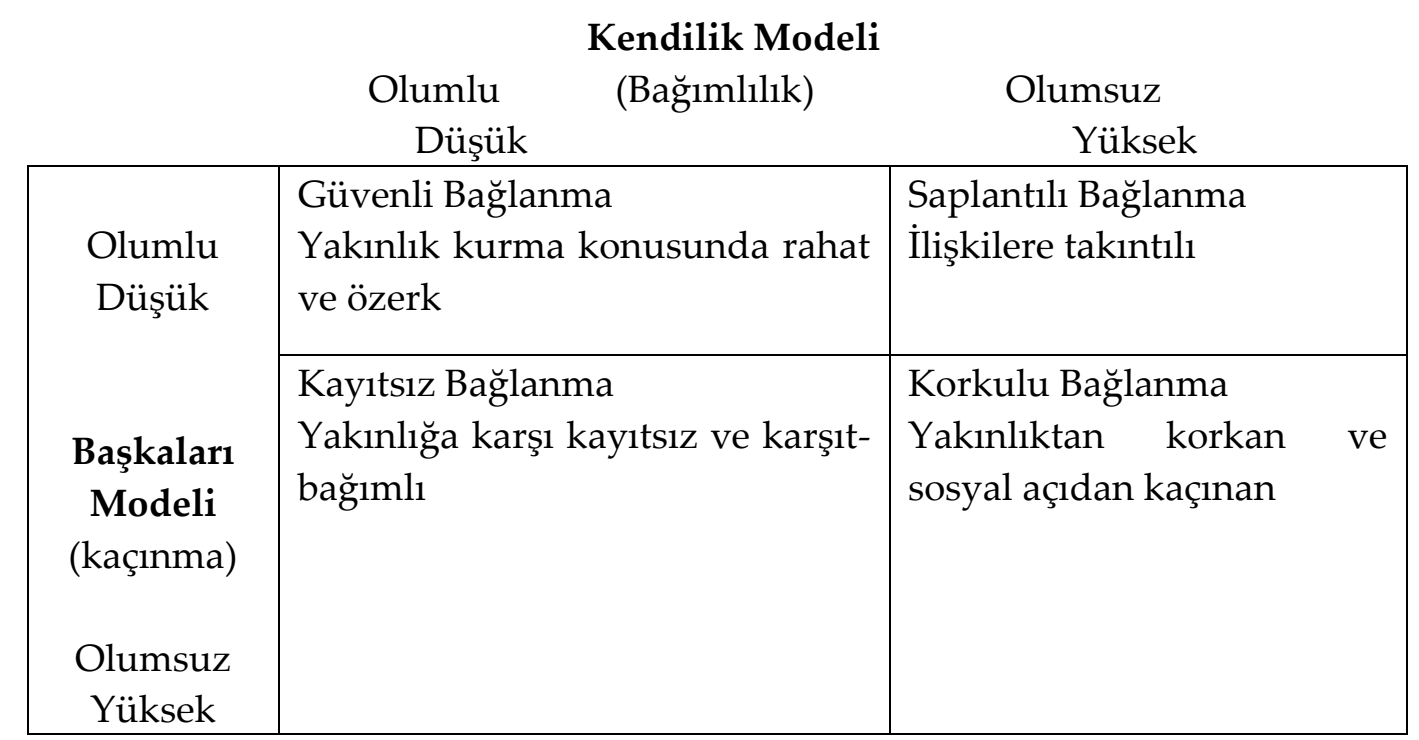

Tabloda da görüldüğü gibi güvenli bağlanma geliştiren yetişkinler kendilerini sevilebilir ve değerli algılamakta aynı zamanda başkalarına karşı da duyarlı davranışlar sergilemektedirler. Bu bağlanma stilindeki bireylerin benlik saygıları yüksektir ve başkaları ile yakınlık kurmaktan rahatsızlık duymazlar. Saplantılı bağlanma stiline sahip yetişkinler kendilerini değersiz bulurlarken başkalarına dair değerlendirmeleri olumludur. Bu durum onların diğerlerinin kabulünü ve onayını kazanmaya çalışmasına ve ilişkilerle çok fazla meşgul olmasına sebep olmaktadır. Bu bağlanma stilindeki yetişkinler diğerleriyle yakın ilişkiler kurmaya çalışırken çok fazla yapışık tarzda hareket ettiğinden diğer kişileri kendilerinden uzaklaştırabilirler. Korkulu bağlanma stilinde ise kişi kendine ve aynı zamanda başkalarına yönelik olumsuz değerlendirmelere sahiptir. Kişi, kendisinin ve başkalarının sevilmeye layık olmadığı inancını taşır. Bu sebeple korkulu bağlanan yetişkinler yakın ilişkilerden kaçınırlar veya ilişkilerinde fazlasıyla sorun yaşarlar. Kayıtsız bağlanma stilindeki yetişkinler ise kendilerini sevilebilir ve değerli olarak değerlendirirken, başkalarına karşı olumsuz değerlendirmelerde bulunurlar. Bu kişiler hayal kırıklığı yaşamamak ve reddedilmemek için başkalarıyla yakın ilişkiler kurmaktan kaçınmakta, bu sayede güçlü ve bağımsız kalarak olumlu benlik algılarını sürdürmek istemektedirler (akt: Çalışır, 2009: 248).

Bağlanma stillerinin romantik ilişkilere ve evlilik uyumuna etkisi üzerine alanyazında pek çok çalışma bulunmaktadır (Banse, 2004; Kobak ve Hazan, 1991; Muşdal Çelebi 2018). Kobak ve Hazan (1991) çalışmalarında içsel çalışan modeller ve güvenliğin (bireyin eşe ve kendine duyduğu güven) evliliğe etkisini incelemişlerdir. Buna göre güvenli bağlanma stiline sahip kişilerin evlilikleri, daha yapıcı ve uyumlu bir görünüm sergilemektedir. Çalışmaya göre ilişkideki uyum her iki çiftin de bağlanma stiliyle ilişkilidir ve her iki çiftin de güvenli bağlandığı ilişkilerde evlilik uyumu yüksektir. Ayrıca çalışmada iletişimdeki açıklığın da evlilik uyumunu arttırdığı görülmüştür. Çalışmanın bir başka bulgusu ise uzun süreli ve karşılıklı anlaşma yoluyla gerçekleşen ilişkilerde ki bireylerin daha fazla güvenli bağlanma geliştirmesidir. Bağlanma stilleri ilişkilerdeki çatışma yönetim biçimleri üzerinde de etkilidir. Buna göre güvensiz bağlanma stilindeki bireyler ilişkilerinde daha tepkisel davranmakta ve eşlerinin davranışlarını olumsuz değerlendirmektediler. Güvenli bağlanma stilindeki 
bireyler ise eşlerinin davranışlarına yönelik geliştirdikleri olumlu atıflar sayesinde daha az çatışma yaşamaktadırlar (Feeney, 2002).

Bowlby (2012) kitabında güvenli bağlanma stilindeki bireylerin ilişkilerinde terk edilme veya yakınlık kurma kaygısı taşımadıklarından, aşk hayatlarında mutlu ve güvenilir olduklarını ifade etmektedir. Ayrıca Kobak ve Hazan (1991)'ın çalışmalarına paralel olarak, güvenli bağlanan bireylerin ilişkilerinin uzun süreliliğine dikkat çekmektedir. Bowbly kaygılı bağlanan bireyleri ise ilişkide iniş çıkışlı ve mücadeleci olarak tanımlamaktadır. Bu kişiler kendilerini sevilmeye layık görmediğinden ilişkilerinde yüksek kıskançlık görülebilmektedir. Kaçınan bağlanma stilindeki kişiler ise yakınlık kurmaktan uzak durmaktadırlar. Bu nedenle ilişkide oldukları kişinin, kendileriyle olması gerektiğinden daha yakın olmaya çalıştığını düşünürler. Bu bireylerde ilişkide oluşturulan bağlar, kişinin yakınlık kurma ihtiyacının çok yoğun olduğunu ortaya koymaktadır. Bununla birlikte ilişkilerde en az bir bireyin güvenli bağlanma stiline sahip olması ilişki doyumunu artırmaktadır (Özenç, 2002). Dolayısıyla çiftlerden herhangi birinin güvenli bağlanması ilişki uyumu üzerinde pozitif etkiye sahiptir. Ülkemizde ise genellikle her iki kişinin de güvensiz bağlandığı evliliklerin yoğunlukta olması (Ertan, 2002) ilişki uyumunun sağlanmasını zorlaştırarak, olası çatışmaların artmasına sebep olabilmektedir.

Tüm bunlarla birlikte evlilik uyumu çok boyutlu değerlendirilmesi gereken bir olgudur. Muşdal Çelebi (2018) çalışmasında kaçınan bağlanma stiline sahip bir kişinin ilişkide partnerine güvenli bağlanabileceğini ve her ilişkinin özel dinamikleri olduğunu belirtmektedir. Bu sebeple evlilik doyumu yalnızca bağlanma teorisi ile ilişkilendirilmemeli ve çok boyutlu değerlendirilmelidir. Evlilik ve ilişki doyumu; aşk türü, cinsel tatmin ve bağlanma türü gibi kişisel boyutları ve karar almada eşitlik, kazanç, iş ve çevre sorunları gibi çevresel boyutları da kapsamaktadır (Sokolsi ve Hendrick, 1999). Aldatma, evlilik uyumunu bozan en önemli faktörlerden biridir. Evlilik uyumunu bozan aldatma olgusu bağlanma stillerini etkilemekte ve aynı zamanda da ondan etkilenebilmektedir. Bireylerin romantik ilişkilerindeki bağlanma stilleri, aldatma ve boşanma gibi süreçleri pekiştirebilmektedir.

\section{Aldatma}

Aldatma oldukça karışık bir konu olarak karşımıza çıkmaktadır. Bu konuda klinik alanyazında oldukça fazla kuramsal düşünce olmasına rağmen, araştırma literatürü seyrek bir görünüm sergilemektedir (Blow ve Hartnett, 2005). Aldatma literatürünün azlığ toplumun aldatmaya ilişkin yaptırımları ile açıklanabilir. Evlilik dışı ilişkiler toplumumuzda sapkınlık olarak görülmektedir. Blow ve Hartnett (2005) aldatmayı metodolojik olarak ele aldıkları çalışmalarında; sadakatsizliğin tanımını iki kişi arasında üzerinde anlaşmaya varılan güvenin ihlali olarak kabul ederek, ilişkide sadakatsizlik olarak tanımlanabilecek tek davranışın açıkça cinsel ilişki olmadığını belirtmektedirler. Buna göre çiftlerin sadakatsizliği nasıl tanımladığı konusunda fikir birliğinin olmaması da ilgili çalışmaları güçleştirmektedir. Blow ve Hartnett araştırma literatüründeki bu zorluğu aşabilmek adına çalışmalarda katılımcıların kimlik bilgilerinin sorulmamasının önemine değinmektedirler. Bu yolla aldatmanın sebep ve sonuçları ile aldatmayı etkileyen faktörlere ilişkin bulgular daha kolay ve güvenilir bir şekilde elde edilebilmektedir.

Aldatma ile ilgili alanyazın incelendiğinde farklı tip aldatma sınıflandırmaları dikkat çekmektedir. Aldatmaya ilişkin sınıflandırmalardaki farklılık; eşlerin her ikisinin mi yoksa 
yalnızca birinin mi aldattığı, aldatmanın cinsellikle mi duygusallıkla mı ilişkili olduğu, aldatmanın gizli olup olmadığı gibi farklı değişkenlerden etkilenmektedir (Tortamış, 2014). Bununla birlikte genel itibari ile dört tip aldatma türü ifade edilmektedir. Bunlar; duygusal aldatma, uzun süreli aldatma, tek gecelik ilişki ve gönül eğlendirme şeklindedir (Subotnik, 2007). Amidon (2007) da aldatma kavramını 4 kategoride ele almaktadır. Bunlar duygusal, cinsel, hem duygusal hem cinsel ve anonim aldatma şeklindedir. Duygusal aldatma; kişinin mevcut ilişkisi varken başka bir kişiyle yakınlaşarak duygusal paylaşımda bulunmasını, cinsel aldatma ise yine kişinin ilişkisi varken başka biriyle cinsel ilişki yaşamasını ifade etmektedir. Bu ikisinin aynı anda olması durumunda ise hem duygusal hem cinsel aldatma kavramı ortaya çıkmaktadır (Blow ve Hartnett, 2005). Aldatma türlerine son yıllarda eklenen anonim aldatma ise son yıllarda oranı giderek artan tek gecelik ilişkileri ifade etmektedir (Amidon, 2007; Kantarc1, 2009).

Aldatmanın sebepleri çok boyutlu ve karmaşık olarak değerlendirilebilir (Thompson, 1982). Weil (1975) çalışmasında aldatmayı hem psikanalitik hem de sosyolojik alanyazına göre değerlendirerek evrensel kültürel mirasın sevgiyi olumlu, cinselliği olumsuz değerlendirme eğiliminde olması ile ilişkilendirmektedir. Bu tutumun sosyalleşme süreci yoluyla her yeni kuşağa aktarıldığını belirten Weil çocuklukta cinselliğe yönelik olumsuz ifadelerin ileriki yıllarda cinsel partnerlere yönelik kötü algı oluşturabileceğini ifade etmektedir. Öte yandan, şefkat ve aşk çocuklukta onaylanan değerlerdendir. Çocuklukta, sevginin şefkati ve fiziksel şehvet ayrı unsurlar olarak öğrenilir ancak yetişkinlikte bireyin evlilik ilişkisinde her ikisini birleştirmesi beklenir. Psikanalitik alanyazın, eşleriyle duygusal tatmin yaşadığı halde cinsel tatmini evlilik dışındaki eşlerde arayan bireylerin var olduğunu ifade etmektedir. Buna göre bazı erkek ve kadınlar bir kişiden sevgi tatmini bir diğer kişiden ise cinsel tatmin arama eğiliminde olabilirler. Yeniçeri ve Kökdemir (2006) aldatmaya zemin hazırlayan faktörleri inceledikleri çalışmalarında; suçlama, sosyal yapı, baştan çıkarma, cinsellik, intikam ve uyaran arayışı kavramlarını ortaya koymuşlardır. Bu kavramlardan suçlama; daha çok kadınların kocalarını aldatma nedenlerini açıklamak için kullanılmaktadır. Sosyal yapı ise kişinin bağlı bulunduğu sosyal çevrenin aldatma eğilimine etkisini ifade etmektedir. Baştan çıkarma; genellikle erkeklerin aldatma nedenlerinde sıkça kullandığı bir kavramdır. Uyaran arayışı ise uzun süreli evliliklerde aldatmaya zemin hazırlayan kavramlardan biri olarak tanımlanmaktadır. Tüm bunlarla birlikte yapılan çalışmalar ilişki tatmini ve aldatma arasında pozitif bir ilişki olduğunu göstermektedir (Polat, 2006).

Aldatmanın sebeplerinden biri de cinsiyet olarak karşımıza çıkmaktadır. Wiederman ve Hurd (1999)`^n çalışmasında ilişki sırasında başka biriyle flört eden erkeklerin oranı \% 44,7 iken kadınlarda bu oran \% 39,5 olarak saptanmıştır. Çalışmada cinsiyet aldatma sebepleri içinde önemli bir değişken olarak belirtilmektedir. Glass ve Wright (1992) de çalışmalarında cinsiyete dayalı aldatma eğilimine değinmektedirler. Buna göre kadınlar daha çok duygusal yakınlık ihtiyacı sebebiyle aldatma eğilimi gösterirken; erkekler ise daha çok kişisel ihtiyaçlar (yenilik arzusu vb.) sebebi ile aldatma eğilimi göstermektedirler. Aldatma eğiliminde ki bir diğer önemli değişken de evlilik yaşıdır. Buna göre erken yaşta evlenen bireylerin aldatma eğilimilerinin daha yüksek olduğu söylenebilir (Atkins, Baucom ve Jacobson, 2001).

Allen ve Baucom (2004) çalışmalarında yetişkin bağlanma stillerinin de aldatma eğilimindeki motivasyonu belirlemede önemli bir değişken olduğunu belirtmektedirler. Bu durumda 
bağlanma stilleri; romantik ilişkilerdeki iletişim motivasyonunu ve aldatma eğilimini belirlemede oldukça etkili görünmektedir. Aldatmayı etkileyen önemli faktörlerden biri de ilişki doyumudur (Polat, 2006). Bu sebeple aldatma kavramını açıklayabilmek için; ilişki doyumunu büyük oranda etkileyen yetişkin bağlanma stillerini incelemek önemlidir.

\section{Boşanma}

Evlilik süresince ortaya çıkan problemlerin çözümlenememesi ve birikmesi sonucu evlilik birliği zedelenmekte ve sonuç olarak boşanma olgusu ortaya çıkmaktadır (Yaşa ve Yıldırım, 2019). Yapılan araştırmalar boşanmanın ülkemizde ve Avrupa'da artma eğiliminde olduğunu göstermektedir (Salman ve Uzunboylu, 2011; Yárnoz-Yaben, 2010). Türkiye'de boşanma hızı 2007-2015 yılları arasında \%26 artmıştır. Bu artışın sabit kalacağı varsayıldığında boşanma hızı altı yıl içinde Avrupa Birliği ortalamasına gelecektir (Kıral, 2018). Türkiye İstatistik Kurumu (2021) verilerine göre 2020 yılında ülkemizde 135 bin 22 boşanma gerçekleşmiştir. Bu veriler boşanmanın gelecekte ciddi problemlerden biri olacağını göstermektedir. Boşanma bireyleri ve toplumu; psikolojik, sosyal ve ekonomik açlardan olumsuz etkilemektedir. Salman ve Uzunboylu (2011) kitaplarında boşanmaya sebep olan bu nedenlerin çok boyutluluğuna dikkat çekerek iktisatçıların boşanmaya sebep olan ekonomik sebeplerle ilgilenirken, psikologların davranış bozuklukları üzerinde yoğunlaştıklarını belirtmektedirler.

Boşanmanın nedenleri incelendiğinde; toplumun boşanmaya ilişkin bakış açısındaki dönüşümler, ekonomik durum, çiftler arası iletişim problemleri, evlilikten beklentilerin karşılanamaması ve kültürel farklılıklar göze çarpmaktadır (Erbay, Gök ve Kardeş, 2015). Boşanma bireylerin psikolojik bütünlügüne zarar vermekte ve ruh sağlı̆̆ını olumsuz etkileyebilmektedir. Boşanma aynı zamanda varsa çocuk ve ebeveyn ilişkisine zarar verdiğinden toplumsal yapıyı temelden sarsmaktadır (Akyüz, 1978).

Weil (1975) boşanma sebeplerinden olan evlilik beklentilerinin karşılanamaması ve iletişim problemlerinin; evlilik doyumunu doğrudan etkileyerek farklı ilişki tatminlerine yönelmede etkili olduğuna vurgu yapmaktadır. Bu durum ilişkilerin aldatma ile sonuçlanmasına ve boşanmalara kadar gidebilmekte, çiftleri ve varsa çocukları olumsuz etkilemektedir. Boşanma sonrası çocuğun ebeveynlerinden biri ile evlerinin ayrılması, ebeveynleri arası ilişkiler ile çocuğun ayrıldığı ebeveynini görme sıklığı gibi değişkenler (Öngider, 2013) çocuklar üzerinde kalıcı duygusal hasarlara sebep olabilmektedir. Nitekim anne babası boşanmış/birlikte yaşamayan çocuklar, boşanmamış/beraber yaşayan çocuklara göre daha fazla güvensiz bağlanma geliştirmektedirler (Sardoğan ve ark., 2007). Boşanmış ailelerin çocukları; ailelerinin yeniden evlenip evlenmemesi, görüşme sıklığı ve diğer faktörlerin de etkisi ile ayrılma kaygısı yaşayabilmekte ve daha fazla kayıtsı bağlanma geliştirebilmektedirler. Dolayısıyla bu durum çocukların yetişkinlik döneminde romantik ilişkilerindeki bağlanma stillerine de yansımaktadır.

Boşanma olgusu toplumsal yapı içinde çok boyutlu değerlendirmeyi gerekli kılan bir konumdadır. Bu çok boyutlu değerlendirmede kişilik özellikleri ve bireysel farklılıklar boşanma sebepleri içerisinde gösterilen; evlilik beklentileri ve iletişim sorunlarının alt yapısını oluşturmaktadır. Nitekim Kobak ve Hazan (1991) çalışmalarında iletişimin evlilik ilişkisindeki önemini açıkça vurgulamaktadırlar. Bu noktada kişisel özellikler; bireylerin bağlanma stillerini, boşanma ile ilişkisi bağlamında değerlendirebilmek açısından önem 
taşımaktadır. Evlilikte bağlanma stilleri ve çiftlerin bireysel bağlanma stillerinin oluşturduğu sentez; iletişim, sadakat ve boşanmaya ilişkin önemli ipuçları vermektedir.

\section{Bağlanma Stilleri ile Aldatma ve Boşanma İlişkisi}

Bağlanma stilleri; kişilerin ilişki doyumları, aldatma eğilimleri ve boşanmaya karar verme süreçleri üzerinde etkilidir (Collins ve Read, 1990; Çavuşoğlu, 2011; Fricker, 2006; Kirkpatrick ve Davis, 1994; Solmuş, 2003). Bu bağlamda bebeklikte gelişen bağlanma stilleri kişinin romantik ilişkilerine doğrudan etki etmektedir. Nitekim Muşdal Çelebi (2018) çalışmasında; bebeklik döneminde bebek/bakımveren arasında gelişen bağlanma örüntülerinin, yetişkinlikte eşle benzer şekilde devam edeceğini belirtmektedir. Çavuşoğlu (2011) da benzer şekilde çocukların bağlanma stillerinin aileleri ile paralel olduğunu ifade etmektedir. Buna gore çocuklukta yaşanan travmalar, yetişkinlikte romantik ilişkilerde aldatma eğilimini arttırmaktadır. Çocukluk travmaları çocukların güvenli bağlanma stili geliştirmelerini zorlaştıracağından, kişinin romantik ilişkilerindeki aldatma eğilimine etki etmektedir. Nitekim Kantarcı (2009) yaptığı çalışmada; güvensiz bağlanma geliştiren yetişkinlerin güvenli bağlananlara göre aldatma eğilimlerinin daha fazla olduğu bulgusuna ulaşmıştır. Bu durum yabancı kaynaklı çalışmalardaki benzer bulguların (Allen ve Baucom; 2004; Yárnoz-Yaben 2010) yalnızca kültürle açıklanamayacağını ortaya koymaktadır. Buna göre ailelerin bağlanma stilleri bir zincir halinde çocuklarının ilişkilerine etki etmekte ve çocukluk deneyimlerinin ilişkilerdeki yansıması aldatma ve boşanma eğilimleri üzerinde etkili olmaktadır.

Kişilerin bağlanma stillerinin romantik ilişkilerdeki yansıması aile yapısını doğrudan etkilemektedir. Bu sebeple farklı tip ilişkilerin özerklik ve mahremiyet motivasyonlarını anlamak; aldatma eğilimlerini incelemeyi kolaylaştırmaktadır. Nitekim Allen ve Baucom (2004) yaptıkları çalışmada kaygılı bağlanma stilindeki kişilerin duygusal olarak daha yakın ve yoğun ilişkilere sahipken kaçınan bağlanma stilindekilerin ise daha sıradan ve mesafeli ilişki yaşadıklarını belirtmektedirler. Bu sebeple de kaçınan bağlanma stiline sahip bireylerin aldatma eğilimleri, kaygılı bağlanmaya göre daha yüksek görünmektedir. Bu durumda kaçınan bağlanma stilindeki kişiler, aldatma ilişkisinde sınırlı temas ve kalıcılık beklentisinin olmaması sebepleriyle evliliğe göre daha fazla yakınlık kurabilmektedirler. Çalışmanın diğer bir bulgusu ise; kaçınan bağlanma stilinin güvenli bağlanmaya göre aldatma eğiliminin daha fazla olmasıdır. Buna göre saplantılı bağlanma gösteren kadınların, güvenli bağlanan kadınlara göre aldatma eğilimleri yüksektir. Yárnoz-Yaben (2010)'nin çalışması da Allen ve Baucom (2004) ile büyük ölçüde paralellik göstermektedir. Buna göre güvenli bağlanma ve evlilik doyumu arasında pozitif bir ilişki bulunmaktadır. Bağlanma ilişkisi ve aldatma arasındaki ilişkinin incelendiği çalışmaların paralellik göstermesi; bağlanma stillerinin; din, dil, kültür gibi ögelerden büyük ölçüde ayrışarak genellenebilir bir bakış sunduğunu ortaya koymaktadır. Bu bağlamda bireylerin bağlanma stillerine ilişkin farkındalıkları ve bu noktada yapılacak çalışmalar, ilişkilerin çözümlenebilmesi noktasında önemlidir.

Bağlanma stilleri kişilerin aldatma eğilimlerini etkilediği kadar (Çavuşoğlu 2011); aldatmaya verilen tepkiler üzerinde de etkili olmaktadır. Evlilik doyumu ve boşanma ilişkisini açıklayan yaklaşımlar; bağlanma kuramı, davranış kuramları ve kriz teorisidir (Karney ve Bradbury, 1995). Bağlanma kuramına göre evlilik, ilişkiden farklı ihtiyaç ve istekleri olan iki kişiyi bir araya getirir. İlişkideki bu ihtiyaçlar değişebilir niteliktedir. Evlenilen kişinin 
ihtiyaçlarını karşılayabilme yeteneği ilişki doyumunu doğrudan etkilemektedir. Bu noktada bağlanma kuramı evlilikteki ihtiyaç ve değişkenlikleri gözden geçirir. Evlenen bireylerin bağlanma ihtiyaçlarının uyumu ve karşılanması evliliğin sürdürülmesinde önemlidir. Nitekim kaçınan bağlanma stilindeki erkekler ile korkulu/kaçınan bağlanma stilindeki kadınlar evlilik beklentilerini karşılamakta zorlanabilmektedirler (Collins ve Read, 1990; Kirkpatrick ve Davis, 1994). Karşılanamayan bağlanma ihtiyaçları boşanmalara sebep olabilir (Karney ve Bradbury, 1995).

Yárnoz-Yaben (2010) yaptığı çalışmada boşanan çiftler arasında güvenli bağlanma gösteren bireylerin daha az olduğunu tespit etmiştir. Nitekim Banse (2004) de çalışmasında güvenli bağlanma gösteren bireylerin ilişki memnuniyetlerinin yüksek, aldatma eğilimlerinin ise düşük olduğunu ifade etmektedir. Ayrıca Yárnoz-Yaben (2004) çalışmasında kaygılı bağlanma stiline sahip bireylerin de tıpkı güvenli bağlanma stilindeki bireyler gibi boşanma eğilimlerinin düşük olduğunu belirtmektedir. Yárnoz-Yaben kaçınan bağlanma stilinin ise başkaları tarafından reddedilmelerinden kaynaklanan acıları en aza indirgemek için davranışlarını savunmacı bir şekilde organize ettiğini ve duygusal ilişkilerini azaltmaya çalıştı̆̆ını belirtmektedir. Bu nedenle de başarısız olduğu bir evliliği sürdürmek, kaçınan bağlanma stilindeki kişiler için olağandır.

Weil (1975) aldatma ile karşı karşıya kalan evliliklerin oldukça fazla olduğunu belirtmektedir. Aldatmadaki cinsiyetler arasındaki farkı ise toplumsal normlarla açıklamaktadır. Bunlara ek olarak Weil aldatma sonrası davranış biçimlerinin cinsiyete göre farklılaştığını ve toplumsal cinsiyet kalıplarının bu noktada kritik önem taşıdığını belirtmektedir. Buna göre oluşan çifte standart, evlilik dışı ilişkisi olan evli kadınların sayısını etkilemekle kalmaz, eşlerin aldatma sonrası affetme ve ilişkiyi sürdürme davranışlarını da etkiler. Boekhout, Hendrick ve Hendric (2003) çalışmalarında erkeklerin aldatıldığ1 ilişkide kadınlara göre daha fazla etkilendiklerini ve kendilerini daha fazla suçladıklarını belirtmektedirler. Bununla birlikte kadınlar aldatıldığı ilişkide, ilişkiyi sürdürmek için daha istekli görünmektedirler. Bu bulgular Weil (1975)'in çalışması ile örtüşmektedir. Aldatma sonrası ilişkilerin ayrılma/boşanma ile sonuçlanıp sonuçlanmayacağ 1 ise değişkenlik göstermektedir. Bu durum aldatılan eşin aldatmaya yönelik atıfları ile ilişkilendirilebilir. Aldatılan eşin partnerinin aldatmasına ilişkin atıfları kişiliğe etiketleme yapmayan geçici atıflarsa (arkadaş çevresi, iş ortamı gibi) ilişkinin devam etme olasılığı artmakta, kalıcı atıflar olduğunda ise (eşin güvenilmezliği gibi) ilişkiyi sürdürme motivasyonu azalmaktadır (Hall ve Fincham, 2006).

Sonuç olarak evlilik ilişkisinin boşanmayla sonuçlanması çok boyutlu bir açıklama ile değerlendirilebilir. Eşler arası uyum ve geliştirilen problem çözme stratejileri bağlanma stilleri ile doğrudan ilişkili olduğu gibi; bireylerin ilişkide yaşanan olaylara verdikleri tepki de bağlanma stilleri ile şekillenebilmektedir. Tüm bu nedenlerle bağlanma stilleri eşlerin ilişki doyumlarını etkileyerek ilişkilerin sadakatsizlik ile sonlanmasına ve boşanmalara sebep olabilmektedir (Kantarc1, 2009).

\section{TARTIŞMA}

$\mathrm{Bu}$ derleme çalışmasında bağlanma stilleri ile aldatma ve boşanma ilişkisi kuramsal olarak ele alınmıştır. Aldatmaya zemin hazırlayan faktörler; ilişkisel ve dışsal faktörler (Duba, 
Kindsvatter ve Lara, 2008) olarak sinıflandırılmakta ve alanyazında bu faktörleri inceleyen pek çok çalışma bulunmaktadır (Atkins ve ark., 2001; Dollahite ve Lambert, 2007; Glass ve Wright, 1992; Hartnett, 2005; Zink, 2008). Bununla birlikte yapılan çalışmalar bağlanma stillerinin; ilişki doyumu ve aldatma eğilimi üzerinde de etkili olduğunu ortaya koymaktadır (Çavuşoğlu, 2011; Fricker, 2006; Solmuş, 2003). Bu durum aldatma eğilimi ve bağlanma stilleri arasındaki ilişkiye işaret etmektedir. Fricker (2006)'in aldatma eğilimini bağlanma stilleri, aşk tarzları ve yatırım modeli çerçevesinde ele aldığı çalışmada; güvenli bağlanma gerçekleştiren bireylerin aldatma eğilimlerinin düşük olduğu görülmüştür. Kaçınan ve korkulu bağlanma stilindeki kişilerin ise aldatma eğilimleri daha yüksek görünmektedir (Cauffman, 1999; Gentzler ve Kerns; 2004; Kantarci 2009). Allen ve Baucom (2004) çalışmalarında kaçınan ve korkulu bağlanma stilindeki kişilerin ilişkilerindeki güvensizlik hissi sebebiyle aldatmaya yönelebileceklerini ifade etmektedirler. Bağlanma stilleri ve aldatma eğilimine ilişkin sözü edilen ortak bulgulara rağmen Tutarel Kışlak ve Çavuşoğlu (2006)'nun evlilik uyumunu bağlanma stilleri ve diğer değişkenlerce incelediği araştırmaları; saplantılı bağlanma stiline sahip bireylerin tıpkı güvenli bağlanma stilinde olduğu gibi evlilik uyumlarının yüksek olduğunu göstermektedir. Bu bulgu ülkemizde kültürel olarak ilişkilerde kıskançlık ve sahiplenmeye yönelik olumlu atıflarla ilişkilendirilmiştir. Aynı zamanda da sosyokültürel değişkenlerin bağlanma stilleri ve ilişki uyumunu etkileyebileceğini göstermektedir.

Aldatmaya verilen tepkiler ilişkilerin devamlılığı noktasında belirleyici olabilmektedir. Nitekim kaçınan ve korkulu bağlanma geliştiren kişilerin ilişkiyi sürdürmekte problem yaşadıkları ve evlilik uyumlarının zayıf olduğu bulgusu (Collins ve Read, 1990; Kirkpatrick ve Davis, 1994) bu bağlanma stilindeki kişilerin aldatma eğilimlerinin yüksek olmasına ilişkin veriler ile paralellik görtemektedir (Bogaert ve Sadava, 2002; Cauffman, 1999; Gentzler ve Kerns; 2004). Aldatma sonrası ilişkinin devamlılığını belireyen faktörler; kültürel normlar, toplumsal cinsiyet rolleri, adatılan eşin aldatmaya ilişkin atıfları ve bağlanma stilleridir (Hall ve Fincham, 2006; Weil, 1975; Yárnoz-Yaben, 2010). Yapılan çalışmalar kaçınan bağlanma stiline sahip bireylerin ilişkiyi sürdürmede daha fazla istekli olduğunu göstermektedir (Yárnoz-Yaben, 2010). Kaygılı bağlanma stilindeki kişiler ise ilişkilerinde yaşadıkları güvensizlik sebebiyle aldatılma korkusu yaşayarak sıklıklı öfkelenebilmektedirler (Davis ve ark., 2003). Bağlanma stilleri ile aldatma ve boşanma ilişkisine yönelik alanyazındaki parallel bulgular konunun önemini ortaya koymaktadır. Bununla birlikte kişilerin sosyokültürel çevresinin bağlanmaları üzerindeki etkileri de araştııılması gereken konulardandır.

\section{SONUÇ VE ÖNERİLER}

Bağlanma stilleri bebeklik döneminde gelişmekle birlikte etkileri hayat boyu sürebilmektedir. Bu durum çocukluk bağlanma stillerine ek olarak bunların yetişkin dönemdeki etkilerinin kısaca yetişkin bağlanma stillerinin önemini ortaya koymaktadır. Yetişkin bağlanma stilleri romantik ilişkilerde uyumu ve davranış örüntülerini açıklamada kullanılan önemli değişkenlerden biridir. Bu durumda romantik ilişkilerde bağlanma stillerine göre; ilişki uyumu, aldatma eğilimi ve boşanma istekliliği gibi pek çok konuda çıkarımlar yapılabilmektedir. Yetişkin bağlanma stilleri ile romantik ilişkileri açıklarken; sosyokültürel ve dini değişkenlerin oluşturacağ 1 farklılaşmalar göz ardı edilmemelidir. Buna rağmen yetişkin bağlanma stilleri ile evlilik uyumu ilişkisi incelendiğinde çalışmalarda ortak 
pek çok bulgu yer almaktadır. Bunlardan en dikkat çekenleri; kaçınan bağlanma stilindeki kişilerin ilişkide yakınlıktan duyduğu rahatsızlık ve kaygılı bağlanma stilinin kendi içinde yaşadığı gelgitli duygularını ilişkiye yansıtması olarak değerlendirilebilir. Ayrıca güvenli bağlanma stiline sahip bireylerin ilişki uyumunun yüksek olması pek çok araştırmada ortaya konulan ortak bulgulardan biridir.

Aldatma ise aldatılan kişide yarattığı etkiler itibari ile yakın ilişkilerde temel güven birliğini zedeleyen bir olgudur. Aldatmanın nedenleri bireysel, sosyal ve kültürel bağlamda ele alınmalı ve çok boyutlu bir şekilde değerlendirilmelidir. Toplumsal olarak küçük yaşlardan itibaren cinselliğe yönelik olumsuz atıflar, aşk olgusunda tamamen olumlu etiketlere dönüşebilmektedir. Bu etiketler çiftleri sosyal öğrenmeler yoluyla etkilemektedir. Nitekim cinsiyet roller gereği kadınların cinselliği yalnızca evlilikte eşi ile yaşaması ve "yuvayı dişi kuş yapar" gibi düşüncelerle aile birliğini sağlaması beklenmektedir. Erkeklerin ise bu konuda edilgen konumda değerlendirilmeleri onlara görece esneklik sağlamaktadır. Aldatma eğiliminde kişisel özellikler önemli bir yer tutmaktadır. Bireylerin bağlanma örüntüleri ilişki doyumunu ve yapısını doğrudan etkilediğinden aldatmanın ortaya çıkıp çıkmamasında da belirleyici olmaktadır. Buna göre kaçınan bağlanma stiline sahip çiftler evlilik ilişkisinde başka partnerlere daha kolay yönelebilmektedir. Bu durum kaçınan bağlanma stiline sahip bireylerin yakınlık kurmaktan kaçınması ile ilişkilendirilebilir.

Aldatma yaşanan her evlilik ilişkisi boşanma ile sonuçlanmamaktadır. Bu noktada evliliği bitiren durumların aldatmaya ilişkin atıflar, diğer sosyo-kültürel, ekonomik değişkenler ve bağlanma stilleri olması beklenebilir. Bağlanma stilleri ilişkilerde aldatmanın boşanma ile sonuçlanıp sonuçlanmayacağı üstünde etkili olmaktadır. Buna göre yapılan çalışmalar kaçınan bağlanma stiline sahip bireylerin ilişkiyi sürdürmede daha fazla istekli olduğunu göstermektedir. Bu durum kaçınan bağlama stilindeki bireylerin ilişkide aradığı mesafe nedeniyle ilişkiyi sonlandırmaya isteksiz olabileceğini göstermektedir. Tüm bu sebeplerle yetişkin bağlanma stilleri; evlilikte aile dinamiklerinden aldatmaya ve hatta boşanma eğilimine kadar etkili olmaktadır.

Bağlanma stilleri ile aldatma ve boşanma ilişkisini ele alan çalışmalar büyük oranda benzer sonuçlar göstermektedir. Bu sebeple kişilerin çocukluktan itibaren geliştirdikleri bağlanma stillerinin aile dinamikleri üzerindeki etkisini kavramak; aile ile çalışan uzmanlar için oldukça önemlidir. Aldatmaya zemin hazırlayan aynı zamanda da boşanma kararına etki eden sürecin temelinde yatan bağlanma stillerinin ortaya konmasının alanyazına ve uygulayıcılara fayda sağlayacağı öngörülmektedir. Çiftlerin ilişkideki bağlanma stilleri, çocuklarına da yansıyarak bağlanma dinamiklerinin kuşaklar arası aktarımına sebep olmaktadır. Nitekim bu etkinin öneminin kavranması; aldatma ve boşanma sürecinde çocukların travmalarını asgari düzeyde tutmaya yardımcı olma noktasında uzmanlara ve ailelere katkı sağlayacaktır. Bu bağlamda alanyazında aldatma ve boşanmaya ilişkin çalışmaların arttırılması gerekmektedir. Bağlanma stilleri ile ilgili çalışmaların paralellik göstermesi özellikle aldatma eğilimi ve boşanma ilişkisinin bu perspektifte incelenmesini gerekli kılmaktadır. İlgili çalışmaların aldatma eğilimi ve boşanmaya ilişkin sorunların çözümüne katkı sağlayacağı düşünülmektedir. 


\section{KAYNAKÇA}

Akyüz, E. (1978). Boşanmanın çocuk üzerindeki etkileri. Ankara Üniversitesi Eğitim Bilimleri Fakültesi Dergisi, 11(1), 1-6.

Allen, E., ve Baucom, D. H. (2004). Adult attachment and patterns of extradyadic involvement. Family Process, 43(4), 467-488.

Atkins, D. C., Baucom, D. H., ve Jacobson, N. S. (2001). Understanding infidelity: Correlates in a national random sample. Journal of Family Psychology,15(4), 735-749.

Banse, R. (2004). Adult attachment and marital satisfaction: Evidence for dyadic configuration effects. Journal of Social and Personal Relationships, 21(2), 273-282.

Bartholomew, K., ve Horowitz, L. M. (1991). Attachment styles among \bung adults: A test of a four-category model. Journal of Personality and Social Psychology, 61(2), 226-244.

Blow, A. J., ve Hartnett, K. (2005). Infidelity in committed relationships I: A methodological review. Journal of Marital and Family Therapy, 32(2), 183-216.

Boekhout, B. A., Hendrick, S. S., ve Hendrick, C. (2003). Exploring infidelity: Developing the relationship issues scale. Journal of Loss andTrauma, 8, 283-306.

Bogaert, A.F. ve Sadava, S. (2002) Adult attachment and sexual behavior. Personal Relationships, 9, 191-204.

Bowlby, J. (1973). Attachment and loss. New York: Basic Books.

Bowbly, J. (2012). Bağlanma. (T. V. Soylu, Çev.) İstanbul: Pinhan Yayıncılık.

Bowbly, J. (2012b). Güvenli bir dayanak. (S. Güneri, Çev.) İstanbul: Psikoterapi Enstitüsü Eğitim Yayınları.

Collins, N. L., ve Read, S. J. (1990). Adult attachment, working models and relationship quality in dating couples. Journal of Personality and Social Psychology, 58, 644-663.

Çalışır, M. (2009). Yetișkin bağlanma kuramı ve duygulanım düzenleme stratejilerinin depresyonla ilișkisi. Psikiyatride Güncel Yaklaşımlar, (1), 240-255.

Çavuşoğlu, Z. Ş. (2011). Bă̆lanma stilleri evlilik uyumu ve aldatma eğilimi arasındaki ilişkinin incelenmesi. Yayımlanmamış uzmanlık tezi, Maltepe Üniversitesi Sosyal Bilimler Enstitüsü Psikoloji Anabilim Dalı Klinik Psikoloji, İstanbul.

Davis, D., Shaver, P. R. ve Vernon, M. L. (2003). Physical, emotional, and behavioral reactions to breaking up: The roles of gender, age, emotional involvement, and attachment style. Personality and Social Psychology Bulletin, $28,871-884$.

Demir, D. (2016). Evlilik uyumu ile bağlanma stilleri ve kişilerarası problem çözme davranışı arasındaki ilişkinin incelenmesi. Yayımlanmamış yüksek lisans tezi, Maltepe Üniversitesi Sosyal Bilimler Enstitüsü, İstanbul.

Duba, J. D., Kindsvatter, A., ve Lara, T. (2008). Treating infidelity: Considering narratives of attachment. The Family Journal, 16-29. 
Dollahite, D. C., ve Lambert, N. M. (2007). Forsaking all others: How religious involvement promotes marital fidelity in Christian, Jewish, and Muslim couples. Review of Religious Research, 48(3), 290-307.

Erbay, E., Gök, F. A., ve Kardeş, T. Y. (2015). Aile mahkemelerine başvuran ve boşanma sürecinde olan ailelerin problem çözme becerilerinin incelenmesi. Türkiye Sosyal Araştırmalar Dergisi, (1), 139-154.

Ertan, Ö. (2002). Bağlanma stillerinin eş seçimi ile kritik ve kritik olmayan evlilik dönemlerindeki doyum üzerindeki rolü. Yayınlanmamış yüksek lisans tezi, Ortadoğu Teknik Üniversitesi, Ankara.

Feeney, J.A. (2002). Attachment, marital interaction and relationship satisfaction: A diary study. Personal Relationships, 9(1), 39-55.

Fricker, J. (2006). Predicting infidelity: The role of attachment styles, lovestyles, and the investment model. Scientific Commans, 67.

Gentzler, A.L. ve Kerns, K.A. (2004). Associations between insecure attachment and sexual experiences. Personal Relationships, 11, 249-265.

Glass, S. P., ve Wright, T. L. (1992). Justifications for extramarital relationships: The association between attitudes, behaviors, and gender. The Journal of Sex Research, 29(3), 361-387.

Gümüş, C. (2017). Ebeveynleri boşanmış 21 yaş ve üzeri yetişkin bireylerin kişilerarası ilişkilerindeki bağlanma modelleri ve ayrılma kaygılarının çeşitli değişkenler açısından incelenmesi, Yayımlanmamış yüksek lisans tezi, Haliç Üniversitesi, Psikoji Anabilim Dalı, İstanbul.

Hall, H. J., ve Fincham, D. F. (2006) Relationship dissolution following infidelity: The roles of attributions and forgiveness. Journal of Social and Clinical Psychology, 25(5), 508-522.

Hazan, C., ve Shaver, P. (1987). Romantic love conceptualized as an attachment process. Journal of Personality and Social Psychology, 52 (3), 511-524.

Kantarc1, D. (2009). Evli bireylerin bağlanma stillerine göre aldatma eğilimleri ve çatışma yönetim biçimlerinin incelenmesi, Yayımlanmamış yüksek lisans tezi, İstanbul Üniversitesi, Sosyal Bilimler Enstitüsü, İstanbul.

Karney, B. R., ve Bradbury, T. N. (1995). The longitudinal course of marital quality and stability: A review of theory, method, and research. Psychological Bulletin, 118(1), 3-34.

Kıral, E. (2018). Avrupa Birliği ülkelerinin boşanma oranı analizi. Uluslararası Ekonomi ve Yenilik Dergisi, 4 (1), 19-38.

Kirpatrick, L. A., \& Davis, K. E. (1994). Attachment style, gender and relationship stability: A longitudinal analysis. Journal of Personality and Social Psychology, 66, 502-512.

Kobak, R. R., ve Hazan, C. (1991). Attachment in marriage: Effects of security and accuracy of working models. Journal of Personality and Social Psychology, 60(6), 861-869.

Muşdal Çelebi, B. (2018). The impacts of adult attachment styles on marital relationships. The International Journal of Human and Behavioral Science, 4(1), 1-8. 
Öngider, N. (2013). Boşanmanın çocuk üzerindeki etkileri. Psikiyatride Güncel Yaklaşımlar, $5(2), 140-161$.

Özenç, E. (2002). The role of attechment styles in partner pairing and satisfaction within marriage in critical and non-critical stages. Yayımlanmamış yüksek lisans tezi, Ortadoğu Teknik Üniversitesi, Ankara.

Öztahtac1, D. (2017). Evli kadınlarda evlilik doyumu, yetişkin bağlanma stilleri ve depresyon düzeyinin ilişkisinin incelenmesi, Yayımlanmamış yüksek lisans tezi, Hasan Kalyoncu Üniversitesi, Sosyal Bilimler Enstitüsü, Psikoloji Anabilim Dalı, Gaziantep.

Polat, D. (2006). Evli bireylerin evlilik uyumları, aldatma eğilimleri ve çatışma eğilimleri arasındaki ilişkilerin bazı değişkenler açısından incelenmesi, Yayımlanmamış yüksek lisans tezi, Ankara Üniversitesi, Sosyal Bilimler Enstitüsü, Ankara.

Salman, N. ve Uzunboylu, H. (2011). Eşlerin boşanma nedenleri ve eğitimi. Ankara: Pegem Yayınları.

Sardoğan, M., Karahan, F., Dicle, A., ve Menteş, Ö. (2007). Ebeveyne bağlanma düzeyine ve anne-babanın boşanma/birliktelik durumuna göre çocuklarda evlilik çatışmasını alg1lama biçimleri. Ondokuz Mayıs Üniversitesi Ĕ̆itim Fakültesi Dergisi, 23, 12-23.

Selçuk, E., Zayas, V., ve Hazan, C. (2010). Beyond Satisfaction: The role of attachment in marital functioning. Journal of Family Theory ve Review, 258-279.

Sığırc1, A. (2010). Evli bireylerde bağlanma biçimleri ve evliliğe dair inançların evlilik doyumu ile ilişkisinin incelenmesi. Yayımlanmamış yüksek lisans tezi, İnönü Üniversitesi, Eğitim Bilimleri Enstitüsü, Malatya.

Sokolski, D. M., ve Hendrick, S. S. (1999). Marital satisfaction. American Journal of Family Therapy, 26(1), 39-49.

Solmuş, T. (2003). Romantik bağlama (II) ilişkisel değişkenler ve ilişki süreci. Türk Psikoloji Bülteni, 9(28-29), 99 - 208

Subotnik, R. (2007). Cyber-infidelity. In P. R. Peluso (Ed.). Infidelity: A practitioner's guide to working with couple in crisis içinde. (pp. 169-190). New York: Taylor and Francis.

Thompson, A. P. (1982). Extramarital relations: Gaining greater awareness. The Personnel and Guidance Journal, 61(2), 102-105.

Tortamış, M. (2014). Evli bireylerde romantik kıskançlık düzeyi ve aldatma eğiliminin şema terapi modeli çerçevesinde değerlendirilmesi. Yayımlanmamış yüksek lisans tezi, Hacettepe Üniversitesi, Sosyal Bilimler Enstitüsü, Ankara.

TUIK (2021). Türkiye istatistik kurumu, evlenme ve boşanma istatistikleri 2020. 28 Ekim 2021 tarihinde https://data.tuik.gov.tr/Bulten/Index? $\mathrm{p}=37211 \&$ dil=1 adresinden erişildi.

Tutarel Kışlak, Ş. ve Çavuşoğlu, Ş. (2006). Evlilik uyumu, bağlanma biçimleri, yüklemeler ve benlik saygısı arasındaki ilişkiler. Aile ve Toplum, 3(9), 61-68.

Erdoğan Taycan, S., ve Çepik Kuruoğlu, A. (2014). Evlilik uyumu ile bağlanma stilleri ve mizaç ve karakter özellikleri arasındaki ilişkilerin incelenmesi. Türk Psikiyatri Dergisi, 25(1), 9-18. 
Uzun, K. N. (2017). Bağlanma stilleri ile evlilikte ilişki istikrarı arasındaki ilişkinin incelenmesi. Yayımlanmamış yüksek lisans tezi, İstanbul Ticaret Üniversitesi, Sosyal Bilimler Enstitüsü, Eğitim Bilimleri Anabilim Dalı, İstanbul.

Varlık Özsoy, E. (2015). Bağlanma, anksiyete ve bilgi işleme. Yayımlanmamış doktora tezi, Ankara Üniversitesi, Sosyal Bilimler Enstitüsü, Klinik Psikoloji Anabilim Dalı, Ankara.

Weil, M. W. (1975). Extramarital relationships: A reappraisal. William Peterson College of New Jersey, 723-725.

Wiederman, M. W., ve Hurd, C. (1999). Extradyadic involvement during dating. Journal of Social and Personal Relationships, 16(2), 265-274.

Yárnoz-Yaben, S. (2010). Attachment style and adjustment to divorce. The Spanish Journal of Psychology,13(1), 210-219.

Yaşa, C., ve Yıldırım, M. S. (2019). Ebeveynleri boşanmış yetişkin bireylerin kişilerarası ilişkilerinde bağlanma modelleri ile ayrılma kaygısının ilişkisi. Anemon Muş Alparslan Üniversitesi Sosyal Bilimler Dergisi, 7(4), 267-278.

Yeniçeri, Z., ve Kökdemir, D. (2006). University students' perceptions of, and explanations for, infidelity: The development of the infidelity questionnaire (INFQ). Social Behavior And Personality, 34(6), 639-650.

Zink, D. W. (2008). The practice of marriage and family counseling and conservative Christianity. J. Duba Onedera (Ed.). The role of religion and marriage and family counseling içinde. (pp. 55-72). New York: Taylor and Francis. 